\title{
Providing rationale for the possibility of decommissioning Bilibino nuclear cogeneration plant based on the onsite disposal option ${ }^{*}$
}

\author{
Igor A. Engovatov ${ }^{1}$, Rinat Kh. Adiyatullin ${ }^{2}$ \\ 1 National Research University Moscow State University of Civil Engineering (NRU MSUCE), 26 Yaroslavskoye shosse, Moscow, 129337, Russia \\ 2 Startech Co. Ltd., 84 Metallurgov St., room 26, Yekaterinburg, 620131, Russia \\ Corresponding author: Lyudmila M. Danilenko (Danilenko_L@bsu.edu.ru)
}

Academic editor: Georgy Tikhomirov • Received 24 January 2020 Accepted 25 August 2020 • Published 6 November 2020

Citation: Engovatov IA, Adiyatullin RK (2020) Providing rationale for the possibility of decommissioning Bilibino nuclear cogeneration plant based on the onsite disposal option. Nuclear Energy and Technology 6(3): 195-201. https://doi.org/10.3897/ nucet.6.58969

\begin{abstract}
The problem of the NPP decommissioning after the end of the specified or extended life has reached the practical solution stage for countries possessing a nuclear power industry. The major decommissioning options, both in Russia and abroad, include immediate dismantling and deferred dismantling. At the same time, there are NPP units for which, for a number of reasons, none of the two options are acceptable in terms of ensuring the safety of the personnel, the public and the environment. Disposal, the third and a more rare option, shall be used for decommissioning in this case. The purpose of the work is to provide rationale for the possibility of decommissioning Bilibino Nuclear Cogeneration Plant based on the Onsite Disposal option by covering the main building with an inert material with the formation of a mound. The option has been selected considering the results of an integrated analysis taking into account the geographical, operational, radiological, and socioeconomic factors, as well as based on a limited experience of decommissioning commercial uranium-graphite reactors both within and outside Russia. In accordance with Russian law, the decommissioning stage will start after spent nuclear fuel is withdrawn from the unit and removed. Emphasis is placed on the proposed option preparation and implementation issues. Dates and sequences for the performance of operations to dismantle the components and civil works of buildings and structures, as well as the onsite protective mound formation structure and composition are discussed. The geometrical dimensions, as well as the quantities and types of the mound-forming materials have been estimated. The key mound-forming materials will be fragments of the components, the biological shielding, and the civil works, as well as local materials.
\end{abstract}

\section{Keywords}

Decommissioning, NPP unit, decommissioning option, onsite disposal, radiation safety, radioactive waste, dismantling of components, buildings and structures

* Russian text published: Izvestiya vuzov. Yadernaya Energetika (ISSN 0204-3327), 2020, n. 2, pp. 73-84. 


\section{Introduction}

Presently, there are over one hundred reactor plants worldwide which are in the process of being or prepared to be decommissioned, including NPP units, research reactors, production reactors, etc. Decommissioning options depend on the national context, the prospects for the nuclear power evolution in the given country, as well as social, technoeconomic, technological and many other factors (Laraia 2012, Decommissioning Strategies 2007, Engovatov et al. 2005, Selecting Strategies 2006). The base options in all leading countries with nuclear power are immediate or deferred reactor plant dismantling. At the same time, there are plants the preferred option for which (Russia), with regard for their designs and operating histories, will be onsite disposal or entombment (in Western terms) (Engovatov et al. 2005, Bolshov et al. 2015, Linge and Abramov 2017). This option suggests that radioactively contaminated components (including the reactor vessel) are confined or localized by being accommodated inside of the containment or barriers of concrete or other protective materials preventing unauthorized access and ensuring radiation safety of the personnel, the public and the environment throughout the time period until exempted from regulatory control. Such decommissioning option is the one used to the smallest extent in practice. In Russia, such approach is taken largely for production reactors (PUGR) [7, 8]. In the USA, this strategy has been implemented only for three nuclear power reactors out of more than forty decommissioned or under decommissioning. However, there is a growing global interest in the strategy in question as applied to reactor plants of generation I (Laraia 2012, Linge and Abramov 2017).

Bilibino Nuclear Cogeneration Plant (BiNCP) stands out among all of the NPPs in Russia. BiNCP is the pioneer of nuclear power in the Russian Trans-Polar region built on permafrost, and a unique life-support facility at the center of Chukotka (town of Bilibino) for the local ore and gold mining enterprises $(800 \mathrm{~km}$ to the south of Pevek, $2000 \mathrm{~km}$ to the north of Magadan, and $12000 \mathrm{~km}$ off Moscow) (Bilibino NPP). The climatic conditions in Bilibino are nearly extreme. Winter lasts for more than 10 months a year with winter temperatures being occasionally as low as $-55^{\circ} \mathrm{C}$. The town is surrounded by mountains and by hundreds kilometers of lakes and swamps due to which it is accessible by air from Pevek and Magadan or by road (in winter).

The plant consists of four single-type power units of the total electric power $48 \mathrm{MW}$ with EGP-6 water-cooled water-moderated heterogeneous pressure-tube reactors.

Following the connection of Akademik Lomonosov, the world's first floating nuclear cogeneration plant (FNPC), to Chukotka's power grid, BiNCP that has had its specified and extended life expired is to be decommissioned.

Any NPP decommissioning option is known to be based on results of a multifactor analysis including political, organizational and technical, socioeconomic, technological and operational factors. The key points of the decommissioning strategy implementation (Selecting Strategies 2006, Bylkin and Engovatov 2014, Decommissioning of Facilities 2014) are
- ensuring the radiation safety of the personnel, the public, and the environment;

- minimizing the radioactivity release and the radioactive waste (RW) quantities;

- achieving a high technical and economic and social efficiency.

In accordance with Russian regulations, the decommissioning stage starts after spent nuclear fuel is removed from the NPP unit (Decommissioning of Facilities 2014). Since the paper deals exactly with decommissioning, no SNF handling, interim storage, and removal issues are considered here. (The potential BiNCP SNF solution is discussed in (Baryshnikov et al. 2012)).

To provide the rationale for the pre-selection of the BiNCP decommissioning option, such indicators were analyzed as geography, location and climate (permafrost, rock); structural and space-planning solutions for the main and auxiliary buildings; the performance history for the entire period of the plant operation; radioactive contamination of buildings, structures, materials and steelworks; integrity of structures in historical mounds; remoteness from RW burial sites; and experience in decommissioning of uranium-graphite reactors (PUGR).

Based on the analysis results, a conclusion has been made that onsite disposal using mound technology components should be regarded as the rational, safe and cost-effective BiNCP decommissioning option (Korovkin and Tutunina 2012, IAEATECDOC-1124 1999).

\section{Characteristics of BiNCP's buildings and structures}

The BiNCP site plan, along with the main buildings and structures, is shown in Fig. 1.

The NCP's main building includes four power units with EGP-6 reactors.

The building's footprint is $108.8^{\prime} 78.0 \mathrm{~m}^{2}$. The elevations are in a range of -8.80 to $22.50 \mathrm{~m}$.

The plant has the following compartments: an indoor switchgear (ISG) compartment, a turbine compartment, a deaerator and control room compartment, a reactor compartment, and a combined auxiliary building (CAB).

The plant's key components are the EGP-6 reactor and the primary circuit consisting of two loops. There are loops provided for each reactor, each loop comprising two drum separators and four reactor coolant pumps (RCP) with pipelines and distributor group headers the water from which is distributed among process channels. There is one turbine installed in the reactor unit. The turbine is capable to extract auxiliary heat as well as heat for the residential area and other users. The reactors and the primary circuit components are installed in separate buildings. The reactor compartment also accommodates auxiliary systems: a blowdown water cleaning facility, an air purification and radioactive gas and aerosol suppression system, repair services, and others. 


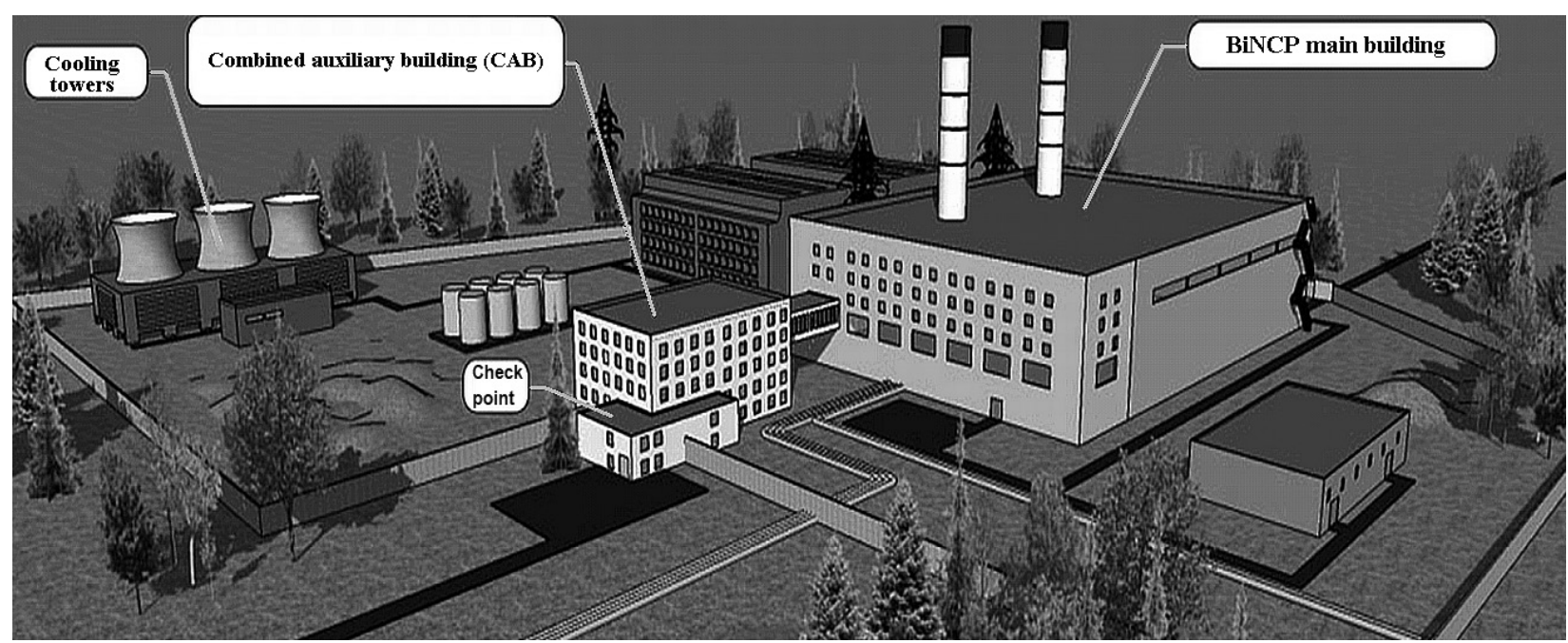

Figure 1. A 3D model of Bilibino NCP.

The turbine compartment is shared by the four power units. It accommodates four turbines with generators and auxiliary facilities including a condensate purification system, low- and medium-pressure reheaters, feedwater pumps, and emergency feedwater pumps.

There is a "rack" between the reactor compartment and the turbine compartment the upper part of which accommodates deaerators and a pipe lane, and the lower one contains the central control room, the main control room, the preferred power switchgears (RUSN), storage batteries, cable cellars, and other electrical devices.

The plant's shared building accommodates auxiliary systems of the mechanical repair service, and the reactor compartment houses liquid and solid waste storage facilities.

The main building's foundations are designed as a solid rigid in-situ reinforced-concrete slab rigidly connected to the in-situ reinforced-concrete retaining walls.

\section{Organizational and technical arrangements at decommissioning stage}

The entire package of preparatory and decommissioning activities is expected to be carried out largely using local personnel capable of implementing the principle reading "we know the plant and its peculiarities in all respects best of all". Such approach will make it possible to resolve socioeconomic issues involved in long-term support with skilled manpower and to exclude the "information loss" factor, as compared with the other options relating to long-term preservation of the facility under surveillance. The activities to prepare for implementing this option can be started immediately. This is why the entire cycle of activities will be led and performed by the plant personnel.

It is well known that the results of an integrated engineering and radiological survey (IERS) are one of the most important sources of data for selecting the final decommissioning option. And the IERS scope and fo- cus (on the engineering and radiological components) depend on the selected strategy implementation option (e.g., emphasis needs to be placed on the IERS engineering component for the Deferred Dismantling option and on the IERS radiological component for the Immediate Dismantling option) (Bylkin et al. 2009, 2013). In our case, both components are similarly important since the radiological component defines the dismantling sequence for components and structures, and the engineering component defines the technical feasibility of dismantling for individual components without other structures and components collapsing.

Such an in-depth IERS program shall be implemented for the purpose of defining more accurately and obtaining additional data, along with that at hand, and justifying the organizational and technical capabilities for implementing the considered decommissioning option.

Feasibility studies for the selection of the plant decommissioning option are based on investigating the results of surveying the engineering and radiological state of the site and the buildings, structures and components. Design and operating documentation was used for the pre-selection of the decommissioning option. The plant infrastructure, the civil engineering complex, and the industrial potential of Bilibino's enterprises, as well as local resources, like rock and production waste, shall be used in the decommissioning operations.

\section{Key stages of the decommissioning process}

In a simplified form, Fig. 2 presents the key BiNCP decommissioning stages.

We shall consider in brief the proposed list and sequence of operations for each stage beginning with the Preparation for Disposal stage. The list of the buildings and structures to be dismantled in full or in part and to be needed after the decommissioning activities are over 


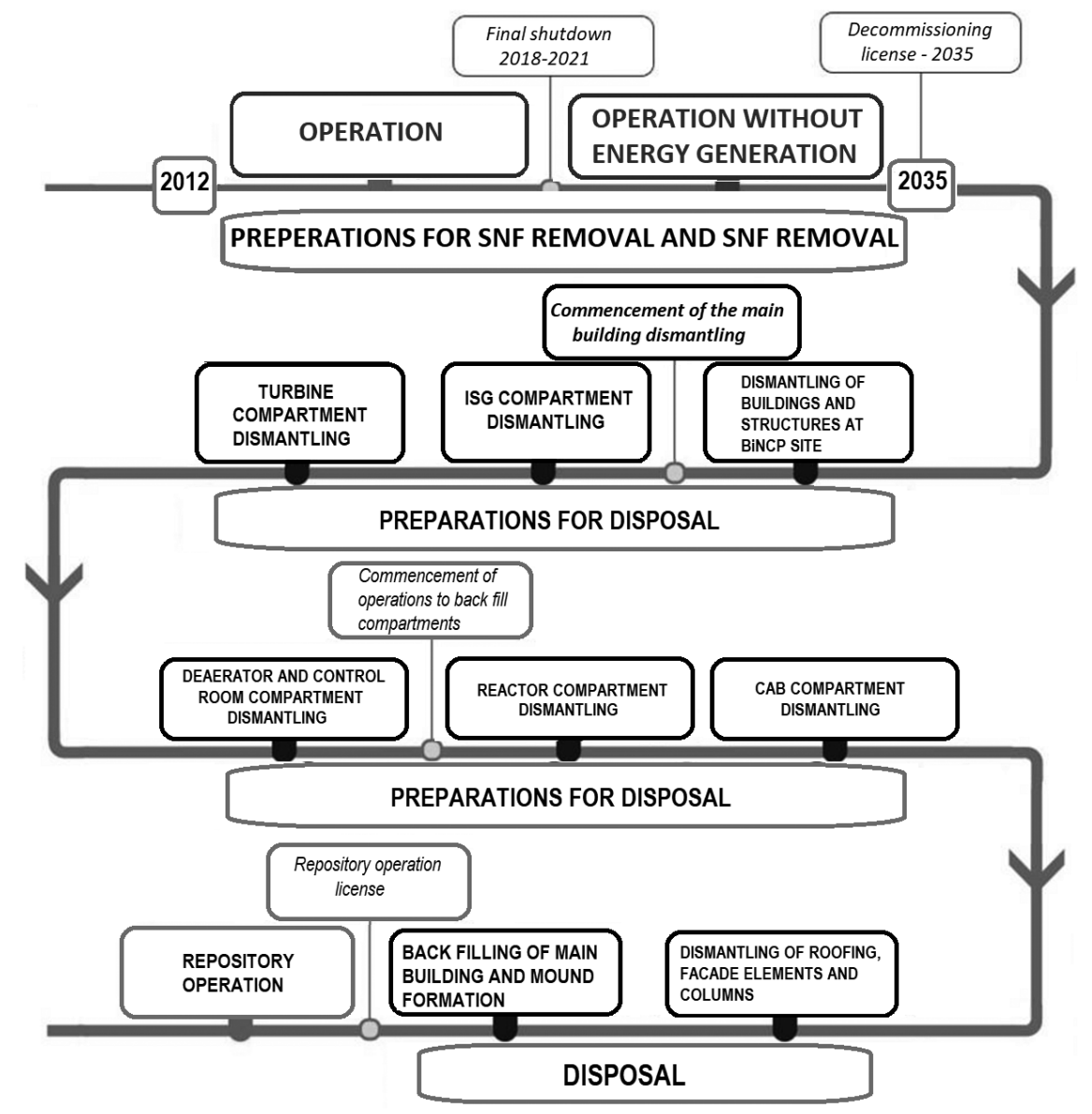

Figure 2. BiNCP decommissioning stages.

is defined at this stage. Besides, quantities of the shelter materials (largely crushed concrete) resulting from decommissioning, and the sources and quantities of other materials (sand, soil and rock from dead gold mines) are estimated. The radioactive waste (RW) types, aggregate state, activity, and quantities are also estimated.

This stage includes seven major substages.

\section{Onsite dismantling of buildings and structures}

Cooling towers, oil facilities, pipelines, and auxiliary buildings and structures are dismantled (largely buildings other than needed for decommissioning and which have the radioactivity in their rooms and components at a residual level). Buildings are left which will be used at all decommissioning stages for guarding the site and monitoring the disposal status.

Nonradioactive components and steelworks are dismantled and removed for being reused and reprocessed. Nonradioactive reinforced-concrete items and structural elements are reprocessed into crushed concrete which is used for preparing the initial disposal layer.

\section{Main building dismantling}

The main building dismantling operations should start with the outer walls and roofing left in place to serve as barriers preventing the escape of radionuclides into the environment. Dismantling is recommended to be performed in the sequence from rooms with minor residual radioactivity to rooms with major residual radioactivity.

The main building dismantling operations should start with the outer wall and roofing left in place to serve as barriers preventing the escape of radionuclides into the environment.

In accordance with this principle, dismantling operations should be started in the indoor switchgear (ISG) boxes and rooms and end with the reactor compartment.

\section{ISG dismantling}

Key operations: equipment decontamination, disassembly of five transformers, auxiliary components and cables, demolition of ceilings and compartment columns. Dismantling is performed from the top downward.

\section{Turbine compartment dismantling}

Key operations: decontamination and disassembly of equipment (turbines, circulation pumps, assemblies, equipment parts, metallic items of pipelines and cooling tower water ducts).

Decontaminated steelworks will be reprocessed for potential reuse or will become, after fragmentation, a part of the first subsurface disposal layer together with the dismantled concrete. Besides, to ensure safety, the reactor 
pits are expected to be back filled with sand at these substages. This stage will require installation of crushing machines to turn reinforced-concrete structures into crushed concrete to cover the building's understructure.

\section{Dismantling of the deaerator and control room com- partment}

Decontamination and dismantling operations will be performed at stage 2 in more radiologically hazardous conditions. Liquid deaeration components, pipelines, electric boards, cables, etc. are dismantled. Further, this compartment's walls and ceilings will be demolished.

\section{Reactor compartment dismantling}

Dismantling of the reactor compartment is the most essential part of the total work scope. Since most of the components will have residual radioactivity, it is expected to require the use of dedicated robotic equipment. Dismantling includes the following activities to be performed successively:

- dismantling of the remaining components, pipelines, the bridge crane, and steelworks;

- fragmentation of dismantled components and steelworks;

- transportation of components, pipelines and steelworks to the disposal site;

- covering of the reactor compartment foundation with sand;

- disassembly of the partition between the deaerator and control room compartment and the reactor compartment;

- crushing of dismantled concrete for the further first layer filling.

\section{Dismantling of the combined auxiliary building (CAB)}

Dismantling of the boxes, rooms and CAB building includes the following activities:
- dismantling of components and pipelines, including pressure pipelines to cooling towers, discharge pipelines from cooling towers, and steelworks;

- fragmentation of components, pipelines, and steelworks for disposal;

- disassembly of walls and ceilings from the top downward;

- crushing of concrete to the state of stone gravel;

- filling the CAB compartment with stone gravel, fragments of components and steelworks intended for online disposal.

The disposal stage consists of two substages.

Dismantling of roofing, the building's façade elements, and the main building columns

Key activities

- dismantling of the roofing;

- dismantling of the façade panels around the building's periphery;

- demolition of all the columns inside of the building.

\section{Filling of the main building and mound formation}

Key operations

- covering of the building's inner and outer parts with sand;

- formation of the shelter structure (the mound model).

The mound model shall take into account the climatic and geological conditions of the terrain. The following model of the BiNCP main building shelter is proposed.

The surface cover is intended to prevent the entry of rainfall and surface water into the shelter body, the erosion of soil and the access of animals, and to exclude the escape of radioactive gases into the atmosphere. The major unfavorable condition will be the erosion of soils which may result in the breakdown of the shelter's upper layer.

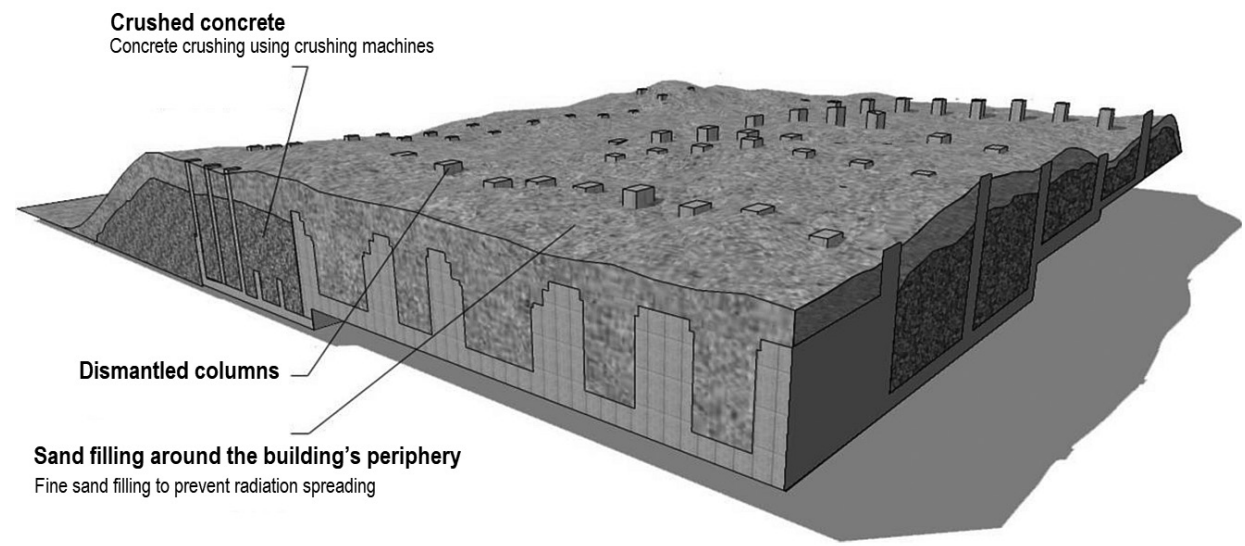

Figure 3. A $3 \mathrm{D}$ model of the BiNCP main building state after the dismantling operations are over. 


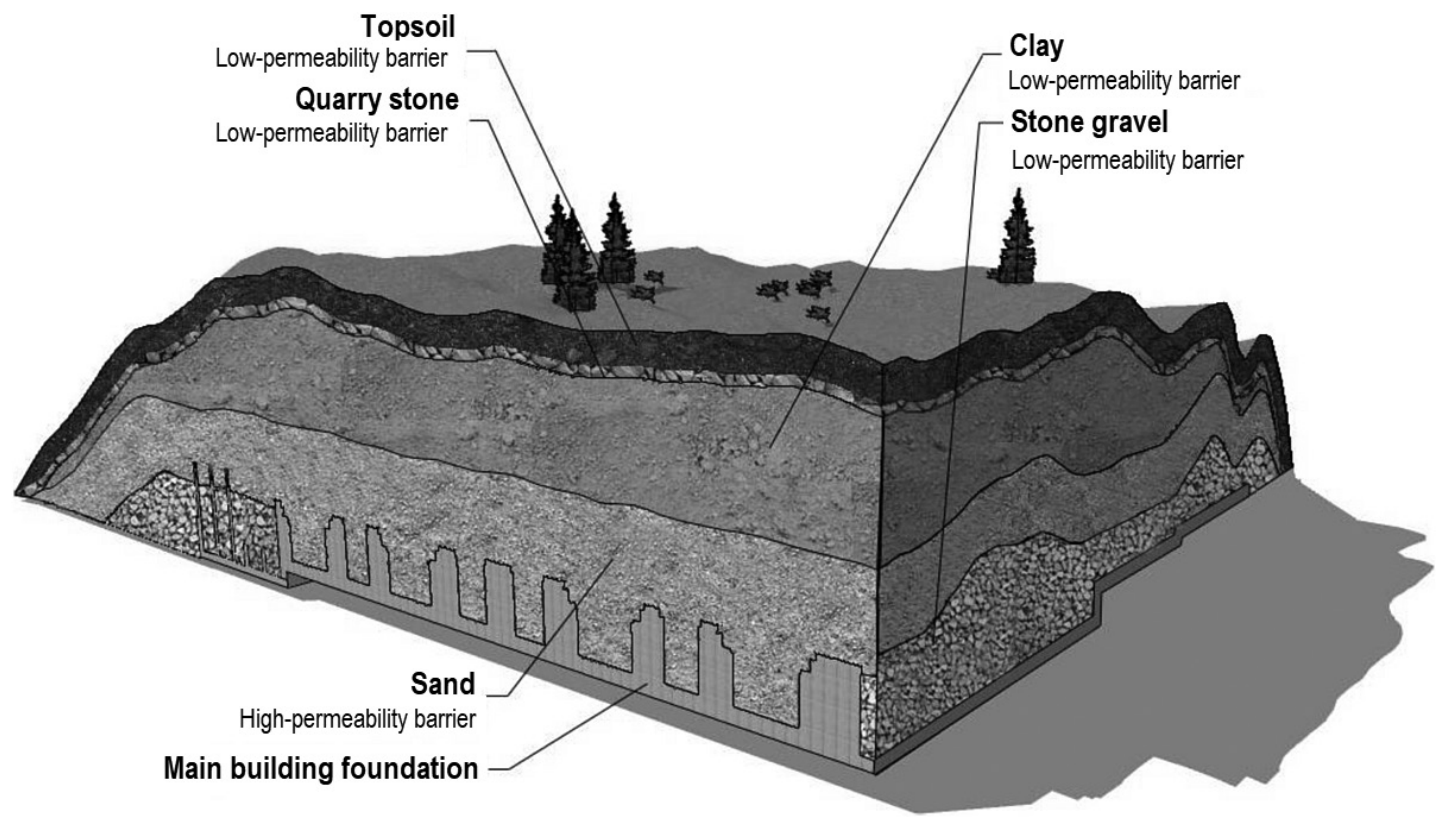

Figure 4. A $3 \mathrm{D}$ model of the BiNCP final state (SRW repository) following the Disposal decommissioning (mound technology).

A system has been proposed consisting of the following barriers

- a low-permeability barrier (sandstones, silt rocks, clayey shale, limestone);

- a high-permeability barrier (clayey and sandy sediments);

- a topsoil barrier (to prevent the cover from being washed away by rainfall).

A 3D model of the BiNCP main building state at the closing dismantling stage with the sand layer filling is shown in Fig. 3, and a 3D model of the BiNCP final state (SRW repository) following the Disposal decommissioning (mound technology) is shown in Fig. 4.

\section{Estimation of the shelter volumes}

The thickness of the inert materials for the back filing and mound formation considered in this paper is not final and represents an approximate estimate. Based on an analysis of the integrated engineering and radiological survey data, it is possible to provide the final calculation of the required soil thickness, including for ensuring the normalized gamma radiation dose rate value on the mound surface.

The preliminary estimates for the mound model are as follows: topsoil $-1 \mathrm{~m}$; quarry stone $-0.5 \mathrm{~m}$; clay $-5 \mathrm{~m}$; sand - from 3.5 to $4.5 \mathrm{~m}$; crushed concrete - up to $15 \mathrm{~m}$.

Schematically, the mound can be represented as a truncated pyramid with the surface dimensions $130^{\prime} 40 \mathrm{~m}^{2}$, the height $23 \mathrm{~m}$ at the elevation $-5.80 \mathrm{~m}$, the flat-top plan dimensions $80^{\prime} 40 \mathrm{~m}^{2}$, and the slope grade 1:2 (Fig. 5).

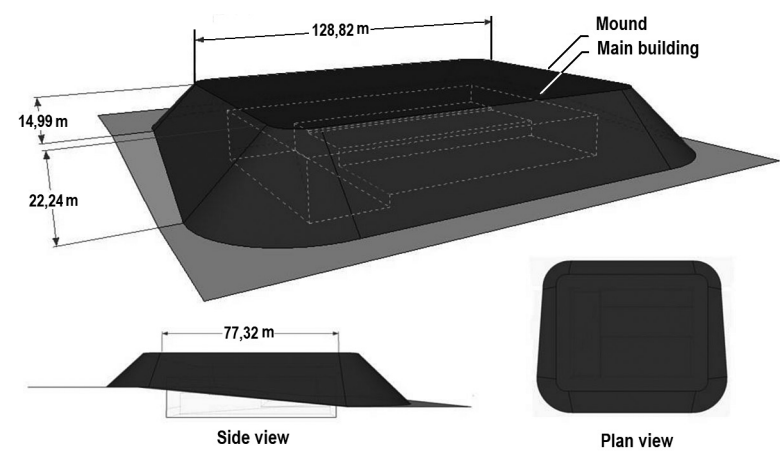

Figure 5. A model of the BiNCP mound based on theoretical data.

The total quantity of the inert materials required for the main building isolation is estimated at about $285000 \mathrm{~m}^{3}$.

\section{Conclusions and findings}

The feasibility of the BiNCP decommissioning for the Onsite Disposal option has been considered.

The major stages and sequence of the decommissioning operations and the final state of the buildings and structures have been recommended.

The shelter model and composition have been proposed, and the quantities of the materials required for the mound construction have been estimated.

The socioeconomic and technological factors behind the selection of the proposed option include the use of the existing infrastructure, the involvement of skilled plant personnel, the absence of costs, and the minimized negative environmental impacts from the RW handling and transportation to the disposal sites. 


\section{References}

- Baryshnikov MV, Suvorova YeV, Khaperskaya AV, Shorokhov NA (2012) Intermediate Results and Prospects of SNF Handling at Bilibino NPP. Bezopasnost yadernykh tekhnologiy i okruzhayushchey sredy 3: 23-28. [in Russian]

- Belkin DYu, Ivanov IA, Tananayev IG (2018) Concept of decommissioning commercial uranium-graphite reactors (PA Mayak, Chelyabinsk Region). Vestnik DVO RAN 3: 58-64. [in Russian]

- Bilibino NPP (2020) https://atomenergy.myl.ru/index/bilibinskaja_aehs/0-7 [accessed 20.01.2020]. [in Russian]

- Bolshov LA, Laverov NP, Linge II (2015) Problems of Nuclear Legacy and Solution Paths. Decommissioning. Moscow, 3, 316 pp. [in Russian]

- Bylkin BK, Engovatov IA (2014) Decommissioning of Reactor Plants. NIU MGSU Publ., Moscow, 228 pp. [in Russian]

- Bylkin BK, Engovatov IA, Zaytsev AN, Zimin VK, Rubtsov PM, Nozdrin GN (2009) Improvement of regulatory documents on NPP decommissioning. Atomnaya energiya 107(6): 307-312. [in Russian] https://doi.org/10.1007/s10512-010-9238-7

- Bylkin BK, Gorelov KA, Engovatov IA, Zaytsev AN, Zimin VK, Rubtsov PM (2013) The requirement for revising the NPP decommissioning regulatory framework. Bezopasnost yadernykh tekhnologiy i okruzhayushchey sredy 1: 34-41. [in Russian]

- Decommissioning of Facilities (2014) General Safety Requirements Part 6 No. GSR Part 6. Vienna, IAEA, 23 pp.

- Decommissioning Strategies for Facilities Using Radioactive Material (2007) Safety Reports Series No 50, IAEA, Vienna.

- Engovatov IA, Mashkovich VP, Orlov YV, Pologikh BG, Khlopkin NS, Tsypin SG (2005) Radiation Safety Assurance: Decommission- ing Nuclear Reactors at Civil and Military Installations. Monography. Arlington, VA 22201 USA 2005. ISTC Science and Technology Series, 4, $201 \mathrm{pp}$.

- Gavrilov PM, Ustinov AA, Antonenko MV, Gorobchenko AD, Sokolov KYu, Zhirnikov DV (2011) Decommissioning of commercial uranium-graphite reactors at Siberian Chemical Combine. Bezopasnost yadernykh tekhnologiy i okruzhayushchey sredy 3: 17-23. [in Russian]

- IAEATECDOC-1124 (1999) International Atomic Energy Agency, On-site disposal as a decommissioning strategy, International Atomic Energy Agency, Vienna.

- Korovkin SV, Tutunina YeV (2012) Mound technology for isolation of decommissioned NPPs // Bezopasnost yadernykh tekhnologiy i okruzhayushchey sredy 3: 37-45. [in Russian]

- Laraia M (2012) Nuclear Decommissioning. Planning, Execution and International Experience. Woodhead Publishing Limited, $805 \mathrm{pp}$.

- Linge II, Abramov AA (2017) Best Foreign Decommissioning Practices for Decommissioning of Nuclear Plants and Rehabilitation of Contaminated Territories. IBRAE RAN Publ., Moscow, 1, 366 pp. [in Russian]

- OPB-2015 (NP-001-15) Federal Regulations and Rules in the Field of Using Atomic Energy. General Provisions for Ensuring the Safety of Nuclear Power Plants. [in Russian]

- Selecting Strategies for the Decommissioning of Nuclear Facilities (2006) Nuclear Energy Agency Organization for Economic Co-Operation and Development/ OECD. 41 pp. 